\title{
Peran BUMDes Dalam Memanfaatkan Dana Desa Untuk Memajukan Kesejahteraan Masyarakat Desa Banyuanyar, Kecamatan Ampel, Kabupaten Boyolali
}

\author{
${ }^{1}$ Yesaya Setia Nugroho Tjokro Rahardjo \\ ${ }^{2}$ Aprina Nugrahesthy Sulistya Hapsari \\ Universitas Kristen Satya Wacana Salatiga \\ Jl Diponegoro No. 52-60, Salatiga, Kecamatan Sidorejo, Kota Salatiga, \\ Jawa Tengah \\ E-Mail: natanyesaya@gmail.com
}

\begin{abstract}
The Indonesian government is currently carrying out overall development both in terms of infrastructure and economically for every corner of the region such as in rural areas. This is evidenced by the assistance in the form of village funds which are given annually by the government. Another proof of rural development is the four development programs launched by the Ministry of Village, Development of Disadvantaged Areas and Transmigration, one of them is the development of Village Enterprises (BUMDes). BUMDes are expected to be the main economic foundation for rural areas so that BUMDes can be a source of income for rural development. This study aims to provide information about the role of BUMDes in managing village funds to improve the prosperity of the Banyuanyar Village community, Ampel District, Boyolali Regency. This study uses a qualitative method by collecting data using analytical triangulation techniques. The results of the study show that BUMDes have performed their roles quite well in the welfare of society. The constraints of BUMDes in Banyuanyar Village refer more to the lack of human resources that can process the village's potential and are still skeptical of the village community about BUMDes itself.

Keywords: Village Enterprises, Prosperity, Village Funds
\end{abstract}

\begin{abstract}
Abstrak
Pemerintah Indonesia saat ini sedang melakukan pembangunan secara menyeluruh baik secara infrastruktur maupun secara ekonomi untuk setiap pelosok daerah seperti di perdesaan. Hal ini dibuktikan dengan bantuan berupa dana desa yang diberikan setiap tahunnya oleh pemerintah. Bukti lain dari pembangunan desa adalah adanya empat program pembangunan yang telah dicanangkan oleh
\end{abstract}


80 Akuntansi Bisnis dan Manajemen (ABM), Vol. 26, No. 2, Oktober 2019

Kemeterian Desa, Pembangunan Daerah Tertinggal dan Transmigrasi, salah satunya adalah pengembangan Badan Usaha Milik Desa (BUMDes). BUMDes diharapkan menjadi pondasi perekonomian utama untuk perdesaan sehingga BUMDes dapat menjadi sumber pendapatan untuk pembangunan desa. Penelitian ini bertujuan untuk memberikan informasi mengenai peran BUMDes dalam mengelola dana desa untuk meningkatkan kesejahteraan masyarakat Desa Banyuanyar, Kecamatan Ampel, Kabupaten Boyolali. Penelitian ini menggunakan metoda kualitatif deskriptif dengan pengumpulan data menggunakan teknis analitis triangulasi Hasil penelitian menunjukkan BUMDes telah menjalankan perannya dengan cukup baik dalam mensejahterakan masyarakat. Kendala yang dimiliki oleh BUMDes di Desa Banyuanyar dalam melakukan perannya lebih mengacu pada kurangnya sumber daya manusia yang dapat mengolah potensi desa dan masih skeptisnya masyarakat desa mengenai kehadiran BUMDes.

Kata Kunci: BUMDes, Kesejahteraan, Dana Desa

\section{PENDAHULUAN}

Indonesia pada saat ini memiliki keinginan untuk menyejahterakan masyarakat secara keseluruhan yang berarti semua golongan masyarakat diseluruh tempat dapat merasakan peningkatan pembangunan ekonomi di Indonesia. Salah satu hal yang dilakukan oleh pemerintah untuk mencapai tujuan tersebut adalah melakukan pembangunan baik secara infrastruktur maupun secara ekonomi di daerah-daerah tertinggal seperti pedesaan. Hal ini dapat dibuktikan dengan adanya bantuan berupa dana desa yang diberikan oleh pemerintah yang mulai diadakan di tahun 2015. Pemerintah mencairkan dana sebesar Rp. 20,7 triliun untuk dana desa pada tahun 2015, dan nominal ini terus meningkat dalam 2 tahun setelahnya yaitu Rp. 46,98 triliun di tahun 2016 dan Rp. 60 triliun pada tahun 2017 (Direktorat Jenderal Perimbangan Keuangan, 2017). Pembangunan ekonomi dan pengetahuan di pedesaan ini memang sangat dibutuhkan dikarenakan pembangunan ini akan memiliki dampak langsung dalam kehidupan masyarakat desa (Budiono, 2015).

Pemerintah melalui Kementerian Desa, Pembangunan Daerah Tertinggal, dan Transmigrasi menetapkan 4 program prioritas yang digunakan untuk melakukan pembangunan desa dalam bidang ekonomi. Salah satunya adalah melakukan pengembangan atas Badan Usaha Milik Desa (BUMDes). BUMDes ini sendiri merupakan badan usaha yang keseluruhan atau sebagian besar dari modalnya berasal dari desa itu sendiri. BUMDes ini memiliki 
peranan dalam mengembangkan setiap unit usaha yang berada dibawahnya sehingga usaha yang dijalankan dapat berkembang dengan baik. Karena hal inilah maka BUMDes dapat menjadi pondasi pembangunan ekonomi masyarakat pedesaan untuk menjadikan desa yang mandiri (Tribun News, 2018).

Desa Banyuanyar merupakan desa yang terletak di Kecamatan Ampel, Kabupaten Karanganyar. Desa ini memiliki visi untuk menjadi green smart vilage. Dalam merealisasikan visi yang telah diberikan, pemerintah memberikan berbagai rancangan dalam melakukan kegiatannya. Adanya bimbingan pelatihan masyarakat desa yang berlandaskan keterampilan sehingga dapat mengolah berbagai macam potensi desa yang ada dan adanya misi "one village one product" menjadi rancangan yang telah dilakukan pemerintah Desa Banyuanyar dalam mencapai visi yang diinginkan. Dalam rancangan yang telah dilaksanakan, banyak usaha yang akhirnya berdiri dengan memanfaatkan berbagai potensi desa yang ada seperti perkebunan dengan memiliki potensi penanaman buah-buahan, banyaknya pertenakan sapi yang berhasil mengolah susu menjadi banyak produk, dan lain sebagainya. Desa Banyuanyar akhirnya membentuk suatu BUMDes yang dinamakan dengan BUMDes Banyuanyar Berkarya dengan banyaknya potensi desa yang berada di desa tersebut. BUMDes ini bertugas mengayomi unit-unit usaha yang berada di Desa Banyuanyar (Pemerintah Desa Banyuanyar, 2017).

Penelitian sebelumnya yang dilakukan oleh Anggraeni (2016), akuntabilitas menjadi permasalahan yang membuat BUMDes memiliki kendala dalam meningkatkan perekonomian masyarakat, kendala lain yang dihadapi adalah kurangnya sumber daya manusia yang mumpuni. Penelitian lain dilakukan oleh Budiono (2015) yang menekankan pada implementasi atas kebijakan pemerintah yang telah diberikan dalam proses berjalannya BUMDes di Desa Ngringirejo, Kecamatan Kalitidu dan Desa Kedumprimpen di Kecamatan Kanor, Kabupaten Bojonegoro. Selain itu Astuti \& Warsito (2017)) dalam penelitian yang terkait dengan BUMDes dalam melakukan fungsi pengawasan terhadap BUMDes di Desa Ponggok Kecamatan Klaten. Ridlwan (2014)serta Ramadana, Ribawanto, \& Suwondo (2013) menilai bahwa BUMDes adalah suatu alat yang dapat memajukan desa menjadi desa yang maju dan sejahtera. Penelitian yang dilakukan oleh Agunggunanto, Arianti, Kushartono, \& Darwanto (2016) menegaskan bahwa BUMDes yang berada di Jepara dapat membangun desa menjadi lebih mandiri.

Berdasarkan paparan diatas, maka penelitian ini ingin melihat peranan BUMDes Banyuanyar Berkarya dalam pengelolaan dana desa untuk mencapai 
tujuan dari BUMDes, terkhususnya untuk mensejahterakan kehidupan masyarakat Desa Banyuanyar. BUMDes Banyuanyar Berkarya ini dipilih menjadi objek penelitian ini karena banyaknya potensi desa yang dimiliki oleh desa tersebut. Terlebih BUMDes ini didukung oleh banyaknya program desa yang telah dicanangkan oleh kepala Desa Banyuanyar seperti adanya desa berbasis keterampilan, sehingga dapat melatih masyarakat desa dalam memanfaatkan potensi desa yang ada serta adanya "one village one product" sehingga setiap dusun dalam desa tersebut memiliki berbagai produk desa yang berbeda sehingga meningkatkan perekonomian masyarakat dengan potensinya masing-masing.

Penelitian ini dapat bermanfaat bagi BUMDes Banyuanyar Berkarya, penelitian ini dapat menjadi evaluasi bagi BUMDes dalam melakukan kinerjanya sebagai badan usaha yang berperan penting dalam memajukan perekonomian masyarakat Desa Banyuanyar, sehingga dapat mengukur dan menilai kinerja yang selama ini telah dilakukan. Selain itu penelitian ini diharapkan dapat bermanfaat untuk Desa Banyuanyar itu sendiri yaitu mendapatkan masukan dan tambahan informasi terkait peran BUMDes dalam mengembangkan potensi desa menjadi lebih baik. Terakhir, penelitian ini diharapkan dapat memberikan manfaat bagi akademik sebagai tambahan literatur terkait dengan BUMDes.

\section{KAJIAN PUSTAKA}

Dana Desa

Undang-Undang No. 6 tahun 2014 mengenai Desa (Presiden Republik Indonesia, 2014b), menjelaskan bahwa salah satu sumber pendapatan desa yang dimiliki berasal dari alokasi Anggaran Pendapatan dan Belanja Milik Negara Penjelasan inipun diperinci pada Peraturan Pemerintah No. 40 tahun 2014 mengenai Dana Desa yang Bersumber Dari Anggaran Pendapatan dan Belanja Negara (Presiden Republik Indonesia, 2014a). Ayat ini menjelaskan bahwa dana desa ini merupakan dana yang berdasarkan pada Anggaran Pendapatan dan Belanja Negara yang ditransfer melalui Anggaran Pendapatan dan Belanja Daerah kabupaten/kota terkait.

Dana desa yang telah berada dalam Anggaran Pendapatan dan Belanja Daerah kabupaten/kota inipun akan dialokasikan kepada beberapa desa yang berada di bawah naungan pemerintahan kabupaten/kota terkait. Dana desa dialokasikan berdasarkan jumalah desa yang dimiliki dalam pemerintahan daerah tersebut. Selain dialokasikan sesuai dengan jumlah desa yang ada, 
pemberian dana desa juga harus diberikan sesuai beberapa kriteria khusus seperti tingkat ekonomi masyarakat, dan lain-lain.

\section{Pengelolaan Dana Desa}

Permendagri No. 113 Tahun 2014 mengenai pengelolaan keuangan desa(Menteri Dalam Negeri Republik Indonesia, 2014), menyatakan bahwa pengelolaan keuangan desa meliputi 5 tahapan yaitu: Perencanaan, Pelaksanaan, Penatausahaan, Pelaporan dan Pertanggungjawaban. Tahapan dalam mengelola keuangan desa dapat dilihat pada Gambar 1.

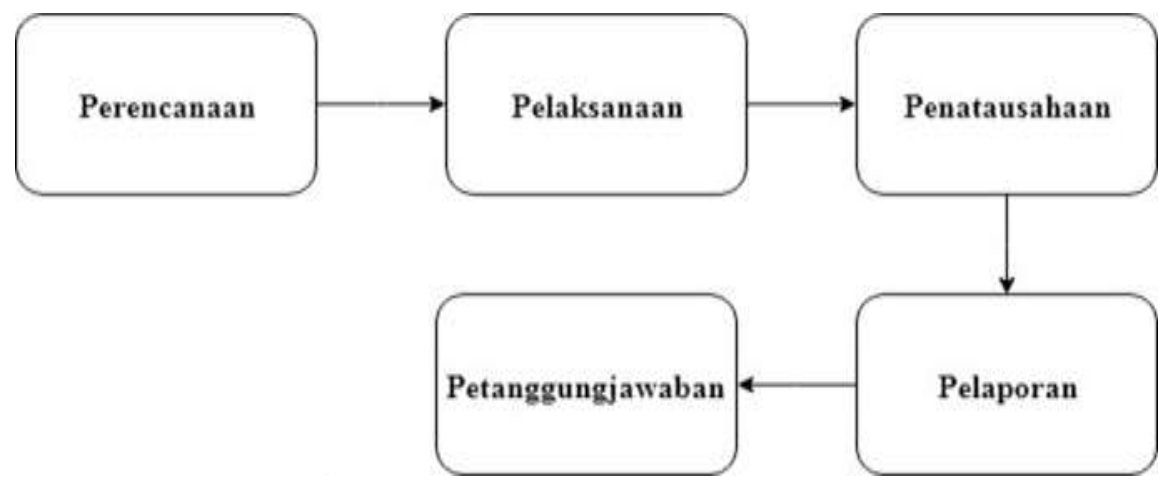

\section{Sumber: Permendagri No 113 Tahun 2014 Gambar 1. Tahapan Pengelolaan Dana Desa}

Tahapan pertama dalam pengelolaan dana desa adalah perencanaan. Sekretaris desa mulai menyusun Rancangan Peraturan Desa APBDesa berdasarkan RPKDesa periode berjalan.lalu menyampaikan rancangan tersebut pada kepala desa. Rancangan tersebut dibawa oleh kepala desa menuju Badan Permusyawatan Desa untuk didiskusikan dan disepakati paling lambat Oktober tahun berjalan. RPKDesa yang telah disepakati lalu dibawa ke Bupati atau Walikota melalui camat untuk dievaluasi dengan hasilnya paling lambat 20 hari selama hari kerja. Bupati atau Walikota jika tidak menetapkan hasil evaluasi, maka peraturan desa yang dirancangkan akan berjalan. Jika RPKDesa dievaluasikan dengan hasil tidak sesuai dengan kepentingan umum, maka kepala desa diharuskan untuk menyempurnakan RPKDesa paling lambat 7 hari setelah hasil evaluasi dikeluarkan.

Tahapan kedua dalam pengelolaan dana desa adalah Pelaksanaan. Semua pengeluaran dan penerimaan desa dilaksanakan dengan rekening kas desa (kecuali tidak ada pelayanan perbankan) dan harus didukung dengan bukti lengkap dan sah. Peraturan mengenai penyimpanan kas desa yang digunakan 
oleh bendahara ditetapkan dalam peraturan Bupati/Walikota. Pengeluaran desa yang mengakibatkan beban APBDesa tidak boleh dilakukan sebelum RPKDesa menjadi peraturan desa kecuali belanja pegawai dan operasional perkantoran yang ditetapkan peraturan kepala desa. Biaya tak terduga yang dimiliki harus dibuat Rincian Anggaran Biaya yang disahkan kepala desa.

Pelaksana kegiatan dalam melakukan pendanaan untuk melakukan kegiatan perlu memberikan bukti berupa dokumen seperti Rencana Anggaran Biaya yang diverifikasi Sekretaris Desa dan disahkan Kepala Desa. Berdasarkan Rencana Anggaran Biaya, pelaksana kegiatan mengajukan Surat Permintaan Pembayaran (SPP) yang terdiri atas: SPP itu sendiri, Pernyataan tanggungjawab belanja, dan lampiran bukti transaksi. SPP yang teah diajukan lalu diverifikasi oleh sekretaris desa yang selanjutnya akan disetujui oleh kepala desa lalu bendahara melakukan pembayaran. Setelah pembayaran maka Bendahara akan mecatatkan pengeluaran yang dilakukan atas kegiatan tersebut.

Tahapan pengelolaan dana desa selanjutnya adalah penatausahaan. Pada tahapan ini, Bendahara desa wajib melakukan pencatatan atas penerimaan dan pengeluaran serta melakukan tutup buku secara tertib. Bendahara menggunakan buku kas umum, buku Kas Pembantu Pajak, serta buku Bank dalam melakukan pencatatan penerimaan dan pengeluaran. Bendahara juga wajib mempertanggungjawabkan uang yang dimiliki dengan membuat laporan petanggungjawaban setiap bulan yang harus disampaikan kepada kepala desa paling lambat tanggal 10 bulan berikutnya.

Tahapan dalam pengelolaan dana desa selanjutnya adalah pelaporan. Tahapan ini memusatkan pada penyampaian laporan realisasi pelaksanaan APBDesa kepada pertama berupa laporan realisasi APBDesa paling lambat bulan Juli tahun berjalan dan laporan semester akhir tahun yang harus disampaikan paling lambat bulan Januari tahun berikutnya. Tahapan terakhir dalam pengelolaan dana desa adalah pertanggungjawaban. Kepala desa memberikan laporan petanggungjawaban realisasi pelaksanaan APBDesa yang terdiri atas: pendapatan, belanja, dan pembiayaan dilaporkan kepada Bupati/ Walikota paling lambat 1 bulan setelah tahun anggaran selesai. Laporan tersebut selanjutnya harus diinformasikan kepada masyarakat dengan secara tertulis dan dengan media informasi yang memudahkan masyarakat untuk menerima informasi tersebut.

\section{BUMDes}

Permendesa No 4 Tahun 2015 mengenai Badan Usaha Milik Desa (Menteri Desa Pembangunan Desa Tertinggal dan Transmigrasi Republik 
Indonesia, 2015), menjelaskan bahwa Badan Usaha Milik Desa merupakan badan usaha yang seluruh atau sebagian besar modalnya dimiliki oleh desa melalui penyertaan langsung yang berasal dari kekayaan desa yang dipisahkan guna mengelola aset, jasa pelayanan, dan usaha lain untuk kesejahteraan rakyat. BUMDes dibuat sebagai upaya mengayomi masyarakat desa baik dalam bidang ekonomi maupun pelayanan publik yang diberikan. Modal awal yang didapatkan oleh BUMDes berasal dari APBDesa yang proses pembuatannya telah dijelaskan pada tahap perencanaan dalam pengelolaan dana desa.

BUMDes dalam melakukan tugasnya memiliki tujuan utama sebagai pengayom masyarakat dalam melakukan kegiatan perekonomian mereka di desa. BUMDes dalam hal ini dapat memberikan pengaruh secara langsung bagi masyarakat dalam meningkatkan perekonomian di desa diantaranya pemberian kemudahan bagi masyarakat dalam menjualkan barang dagangan nya kepada pasar yang berada jauh dari desa, pemanfaatkan sumber daya alam dan lingkungan sekitar desa yang dapat digunakan menjadi sesuatu yang lebih bernilai seperti memproduksi barang dagang maupun menjadikan lingkungan desa menjadi desa wisata, menciptakan banyak lapangan pekerjaan bagi masyarakat desa. BUMDes yang berada di Klaten (Listy 2017) merupakan contoh kecil dari banyaknya BUMDes yang berkembang dan dapat meningkatkan perekonomian desa.

BUMDes memiliki beberapa klasifikasi jenis usaha yang dapat dilakukan oleh setiap unit usaha yang berada di bawah naungan BUMDes. Jenis usaha ini terdiri atas usaha perdagangan (trading), perantara, keuangan, penyewaan, social business dengan melakukan pelayanan umum, maupun usaha bersama yang dijalankan oleh masyarakat desa (Menteri Desa Pembangunan Desa Tertinggal dan Transmigrasi Republik Indonesia, 2015). Penjelasan dan contoh jenis usaha yang dimiliki oleh BUMDes diperlihatkan pada tabel ini. 
86 Akuntansi Bisnis dan Manajemen (ABM), Vol. 26, No. 2, Oktober 2019

Tabel 1. Jenis Usaha BUMDes

\begin{tabular}{|c|c|c|}
\hline Jenis Usaha & Penjelasan & Contoh \\
\hline Perdagangan & \begin{tabular}{lr}
\multicolumn{3}{l}{ Melakukan penjualan atas } \\
barang yang diproduksi \\
atau barang $r$ yang \\
didagangkan & untuk \\
memenuhi & kebutuhan \\
masyarakat atau dipasarkan \\
\multicolumn{2}{l}{ diluar area desa }
\end{tabular} & $\begin{array}{l}\text { BUMDes dapat } \\
\text { menjalankan usaha } \\
\text { penjualan alat tulis kantor } \\
\text { untuk memenuhi } \\
\text { kebutuhan masyarakat. }\end{array}$ \\
\hline Bisnis Sosial & $\begin{array}{l}\text { Melakukan pelayanan sosial } \\
\text { demi memenuhi kebutuhan } \\
\text { masyarakat rengan } \\
\text { mendapatkan keuntungan } \\
\text { finansial }\end{array}$ & $\begin{array}{l}\text { Menyediakan sumber air } \\
\text { desa, listrik desa sehingga } \\
\text { dapat dimanfaatkan oleh } \\
\text { masyarakat }\end{array}$ \\
\hline Penyewaan & $\begin{array}{l}\text { Melakukan persewaan atas } \\
\text { peralatan dan perlengkapan } \\
\text { yang sesuai dengan } \\
\text { kebutuhan. }\end{array}$ & $\begin{array}{l}\text { BUMDes menyediakan } \\
\text { alat bangunan untuk } \\
\text { membantu masyarakat } \\
\text { dalam merenovasi rumah } \\
\text { atau membangun rumah } \\
\text { baru }\end{array}$ \\
\hline Perantara & $\begin{array}{l}\text { Melakukan pelayanan } \\
\text { kepada masyarakat dalam } \\
\text { mengakomodasikan barang } \\
\text { menuju ke pasar sehingga } \\
\text { jalur komoditas barang } \\
\text { masyarakat lebih singkat }\end{array}$ & $\begin{array}{l}\text { Membawa barang dagang } \\
\text { masyarakat (seperti beras) } \\
\text { menuju pasar pusat dengan } \\
\text { lebih cepat dan } \\
\text { mendapatkan harga yang } \\
\text { lebih adil. }\end{array}$ \\
\hline Keuangan & $\begin{array}{lr}\text { Memberikan } & \text { usaha } \\
\text { keuangan } & \text { kepada } \\
\text { masyarakat } & \text { sehingga } \\
\text { membantu } & \text { menumbuhkan } \\
\text { usaha mikro yang dimiliki }\end{array}$ & $\begin{array}{lr}\text { Melakukan } & \text { usaha } \\
\text { pengkreditan atau } \\
\text { pinjaman untuk } \\
\text { masyarakat dengan bunga } \\
\text { yang kecil sehingga tidak } \\
\text { membebankan masyarkat } \\
\text { dalam membayar pinjaman }\end{array}$ \\
\hline Usaha Bersama & $\begin{array}{l}\text { Membangun wadah usaha } \\
\text { yang dapat dijalankan oleh } \\
\text { masyarakat desa dengan } \\
\text { pengelolaan dilakukan oleh }\end{array}$ & $\begin{array}{lrr}\text { Membuat desa } & \text { wisata } \\
\text { dengan membawa } & \text { banyak } \\
\text { lapangan } & \text { kerja } & \text { dari } \\
\text { masyarakat } & \text { desa } & \text { itu }\end{array}$ \\
\hline
\end{tabular}


BUMDes

sendiri.

Sumber: Permendesa Nomor 4 Tahun 2015

Organisasi pengurus BUMDes memiliki anggota diluar pemerintah desa terkait dalam melakukan tugas mereka. Anggota pengurus BUMDes terdiri atas: (1) Penasihat, (2) Pelaksana Operasional, dan (3) Pengawas. Struktur organisasi dari BUMDes dapat dilihat pada Gambar 2.

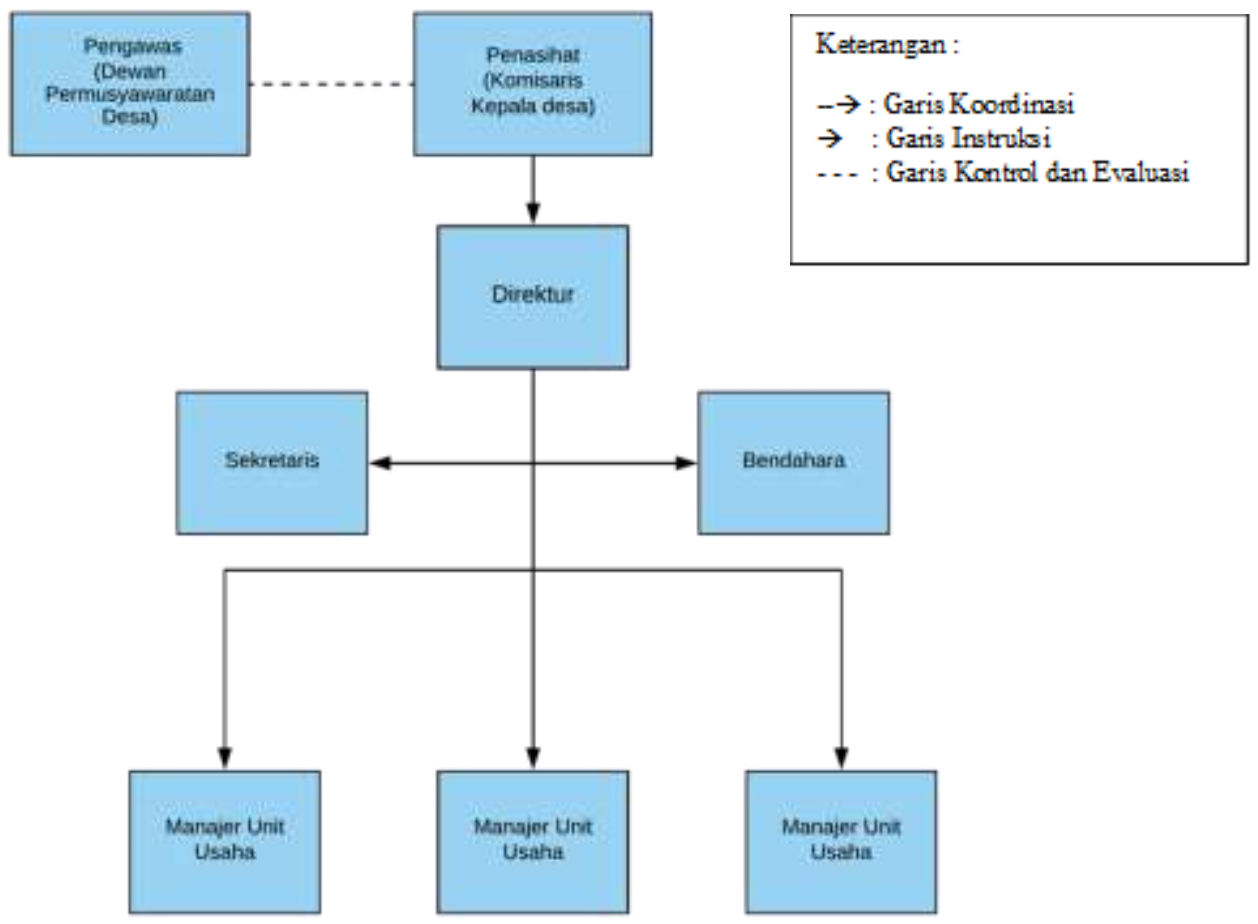

Sumber: Permendesa Nomor 4 Tahun 2015

Gambar 2. Struktur BUMDes

Jabatan penasihat dalam BUMDes merupakan ex officio yang dijabat oleh kepala desa. Penasihat memiliki tugas untuk memberikan nasihat kepada pelaksana operasional dalam melakukan pengelolaan BUMDes dan memberikan saran dan pendapat mengenai masalah yang dianggap penting bagi pengelolaan BUMDes. Pengawas juga memiliki wewenang untuk meminta penjelasan kepada pelaksana operasional terkait masalah dalam pengelolaan BUMDes dan melindungi usaha desa dari hal-hal yang dapat menurunkan kinerja BUMDes. 
Jabatan Pelaksana Operasional memiliki tugas untuk melaksanakan dan mengembangkan BUMDes, memanfaatkan potensi desa yang ada dan dapat bekerja sama dengan lembaga-lembaga perekonomian yang lain. Pelaksana organisasi dalam melakukan tugasnya dapat menunjuk anggota pelaksana dalam mengurus pencatatan dan administrasi usaha sesuai dengan kapasitas bidang usahanya. Pelaksana Operasional memiliki kewajiban untuk: menjalankan dan mengembangkan BUMDes agar menjadi lembaga yang dapat melayani kebutuhan ekonomi masyarakat, memanfaatkan potensi desa yang ada, dan menjalankan kerjasama dengan lembaga keuangan lain. Pelaksana Operasional juga memiliki wewenang untuk melakukan hal-hal berikut: membuat laporan keuangan bulanan bagi setiap unit-unit usaha, membuat laporan perkembangan kegiatan bulanan untuk setiap unit usaha BUMDes, dan memberikan laporan perkembangan unit-unit usaha kepada masyarakat desa melalui musyawarah desa sekurang-kurangnya 2 kali dalam satu tahun.

Jabatan Pengawas memililiki ruang lingkup sendiri sehingga pengawas berperan sebagai perwakilan terhadap kepentingan rakyat. Pengawas memiliki tugas menyelenggarakan rapat umum untuk membahas kinerja BUMDes sekurang-kurangnya satu tahun sekali. Pengawas dalam BUMDes memiliki kepengurusan yang terdiri atas: Ketua, Wakil ketua merangkap anggota, Sekretaris merangkap anggota, dan anggota. Pengawas ini dapat menyelanggarakan rapat umum pengawas untuk menentukan keputusan penting yang harus diambil dalam ruang lingkup pengawas itu sendiri.

\section{METODA PENELITIAN}

Jenis Penelitian

Lokasi penelitian berada di Desa Banyuanyar, Kecamatan Ampel, Kabupaten Boyolali. Objek penelitian ini adalah BUMDes "Banyuanyar Berkarya" dan pemerintah Desa Banyuanyar sebagai pihak yang membuat APBDes. Penelitian ini menggunakan kualitatif deskriptif yang menghasilkan sebuah skema yang berisi semua data yang dibutuhkan dalam menjawab semua pertanyaan yang ada dalam penelitian ini. Penelitian ini menggunakan data primer berupa hasil dari wawancara yang dilakukan oleh peneliti kepada beberapa partisipan serta adanya dokumentasi langsung ke lokasi objek penelitian. Para narasumber yang akan diwawancarai antara lain adalah: Kepala desa, perwakilan dari kepengurusan BUMDes, dan sebagian masyarakat yang merasakan langsung manfaat dari pendirian BUMDes. Dokumentasi langsung juga akan dilakukan untuk mendapatkan bukti-bukti pendukung dalam penelitian ini dalam bentuk gambar dari tempat penelitian. 


\section{Teknik Analisis Data}

Data-data informasi yang telah didapatkan dari wawancara yang dilakukan oleh para partisipan dapat dilakukan dengan beberapa tahapan berikut: reduksi, triangulasi, penyajian data, dan penarikan kesimpulan. Susunan tahapan-tahapan ini dapat dilihat pada Gambar 3.

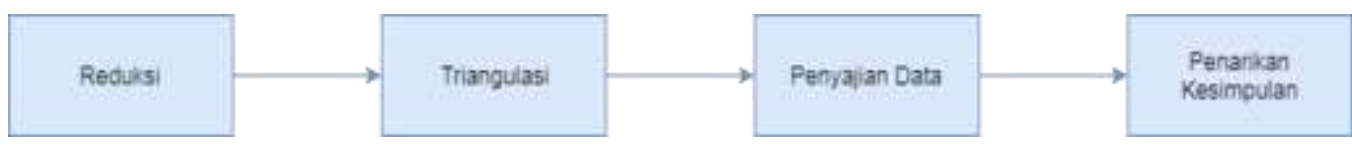

\section{Gambar 3. Teknik Analisis Data}

Dalam tahapan reduksi, semua informasi yang telah didapatkan oleh peneliti dari beberapa partisipan yang ada melalui wawancara akan diringkas sesuai dengan informasi yang diinginkan dan dibutuhkan dalam penelitian ini. Data-data informasi yang telah diringkas lalu dibagi sesuai dengan beberapa klasifikasi-klasifikasi sesuai dengan pertanyaan yang diberikan. Tahapan selanjutnya yang dilakukan dalam menganalisis data informasi ini adalah melakukan triangulasi. Pada tahapan ini, informasi yang telah diringkas tahapan sebelumnya akan dilihat kebenarannya sekaligus mencari bukti pendukung sehingga pernyataan dapat dipercaya. Triangulasi menggunakan tiga cara penelitian untuk dapat mengungkapkan suatu pernyataan. Cara tersebut dalam jurnal ini antara lain adalah wawancara, dokumentasi, dan observasi dalam proses triangulasi. Penyajian data merupakan tahapan selanjutnya yang dilakukan dalam menganalisis data. Penyajian data untuk penelitian ini adalah sebuah skema berupa tabel yang akan menjelaskan kesesuaian antara tujuan pembentukan BUMDes dengan realita yang terjadi di lapangan. Teknik terakhir dalam analisis data adalah pengambilan kesimpulan. Tahapan ini dilakukan oleh peneliti untuk mengetahui kesesuaian proses kegiatan yang dilakukan suatu organisasi dengan tujuan yang telah dibuay terkhususnya dalam mensejahterakan masyarakat.

\section{HASIL DAN PEMBAHASAN Gambaran Objek Penelitian}

Objek penelitian ini adalah Desa Banyuanyar yang berada di Kecamatan Ampel, Kabupaten Boyolali. Nama "Banyuanyar itu sendiri berasal dari sebutan masyarakat atas adanya sumber mata air secara mendadak. Sumber mata air yang keluar membuat banyak orang berkata, "Eneng banyu seng anyar! Eneng banyu seng anyar!" yang artinnya adalah ada sumber air yang baru. Adanya sumber air baru inilah yang membuat nama desa ini menjadi Desa Banyuanyar. 
Desa Banyuanyar memiliki visi menjadi desa yang menerapkan "Green Smart Village". Visi ini diberikan langsung oleh kepala Desa Banyuanyar yaitu Bapak A tahun 2016 dengan keinginan menjadikan masyarakat Desa Banyuanyar lebih bertakwa sekaligus dapat memanfaatkan teknologi yang sudah ada untuk mengolah berbagai potensi desa yang dapat dikembangkan. Misi-misi yang digunakan untuk merealisasikan visi Desa Banyuanyar terdiri atas adanya pelatihan berbasis keterampilan, penambahan fasilitas teknologi, adanya program "One village one product" yang dapat memaksimalkan setiap potensi yang ada di setiap dusun.

Desa Banyuanyar memiliki 4 wilayah dusun yaitu kadus 1 yang diisi oleh Dukuh Rekuning, Dukuh Grenjeng, Dukuh Banyuanyar, Dukuh Geneng, kadus 2 yang diisi oleh Dukuh Bunder dan Dukuh Ngemplak, kadus 3 yang diisi oleh Dukuh Dukuh, dan kadus 4 yang diisi oleh Dukuh Wangan dan Dukuh Jumbleng. Lokasi dari dukuh-dukuh yang berada di Desa Banyuanyar ini dapat dilihat oleh Gambar 3

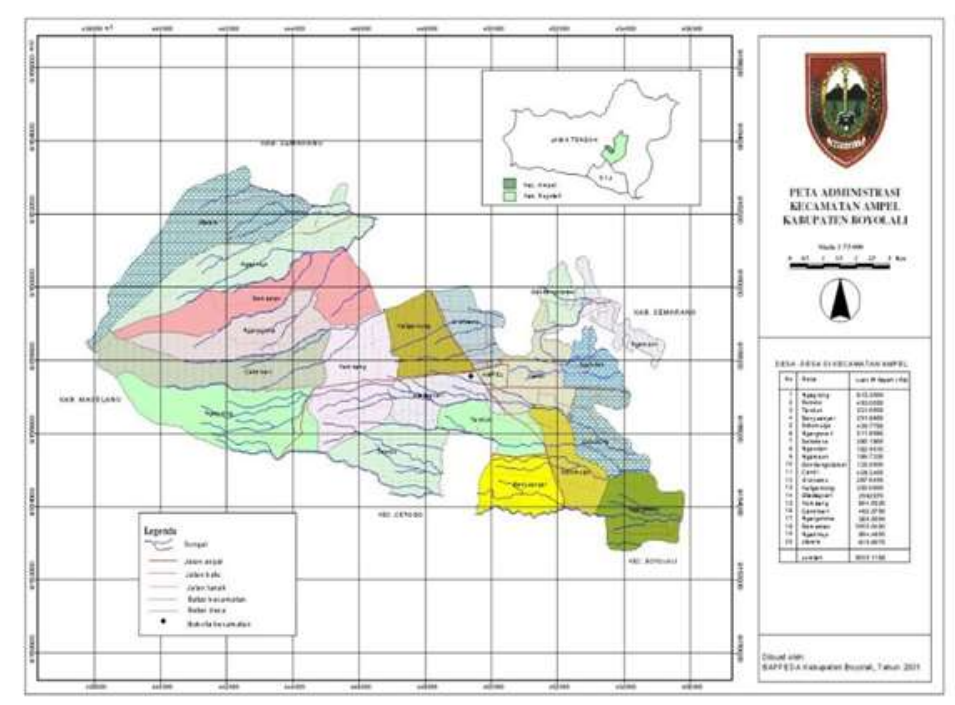

\section{Gambar 4. Peta Desa Banyuanyar}

Desa Banyuanyar berada di dataran yang cukup tinggi dengan kondisi tanah yang subur, sehingga sangat cocok untuk dibuat menjadi lahan pertanian. Kondisi dataran yang dimiliki juga membantu masyarakat dalam melakukan 
kegiatan perkebunan seperti menanam biji kopi dan peternakan seperti sapi. Keseluruhan lingkungan dalam Desa Banyuanyar ini dapat membantu masyarakat untuk mengembangkan usaha bagi para pengusaha dengan membuka usaha yang berlandaskan potensi desa yang ada dikarenakan kondisikondisi yang telah diberitahukan sebelumnya serta jalan utama Desa Banyuanyar yang saat ini sangat mendukung dalam penyaluran barang desa ke luar area desa.

\section{BUMDes Banyuanyar Berkarya}

BUMDes Banyuanyar Berkarya dibentuk oleh hasil musyawarah yang dilakukan oleh Kepala Desa bersama dengan para tokoh penting yang berada dalam Desa Banyuanyar seperti para kelompok masyarakat, tokoh masyarakat, tokoh agama, dan beberapa masyarakat sesuai dengan kondisi desa. BUMDes Banyuanyar Berkarya berdiri pada tanggal 4 November 2016, ditandai dengan berlakunya Peraturan Desa No. 11 Tahun 2016 mengenai pembentukan BUMDes Banyuanyar Berkarya. BUMDes Banyuanyar Berkarya memiliki bentuk berupa Perusahaan Desa dengan mengelola unit-unit usaha yang berlandaskan badan hukum. BUMDes Banyuanyar Berkarya dibentuk sebagai upaya menampung seluruh kegiatan perekonomian sekaligus pelayanan umum yang dikelola oleh desa. Pengembangan usaha yang berdasarkan potensi desa yang dapat dimanfaatkan oleh desa, pemberian pelayanan umum yang luas dan pemberian lapangan kerja adalah misi yang dimiliki oleh BUMDes Banyuanyar Berkarya. Hal ini diungkapkan oleh Bapak B sekretaris Desa Banyuanyar yang dahulunya merupakan direktur BUMDes Banyuanyar Berkarya.

\section{“...Potensi desa ini sudah ada, kita survey mas sampai bertahun- tahun melihat prospek apa saja yang bisa dimanfaatkan supaya bisa bernilai. Ada penambahan unit usaha supaya banyak masyarakat juga mendapatkan pekerjaan. BUMDes juga akan mendukung usaha-usaha kecil milik masyarakat..."}

Sumber dana yang didapatkan oleh BUMDes Banyuanyar Berkarya berasal dari APBDesa yang telah dicanangkan oleh pemerintah Desa Banyuanyar pada setiap tahun. BUMDes dalam APBDesa telah memberikan anggaran sendiri atas pembelanjaan yang akan dilakukan oleh BUMDes dalam satu tahun. Selain pendanaan yang didapatkan dari APBDesa, dana yang didapatkan oleh BUMDes dapat berupa bantuan yang berasal dari Kabupaten Boyolali, atau dari pihak ketiga. Dana yang didapatkan oleh BUMDes dapat digunakan untuk memudahkan dalam melakukan kegiatan operasionalnya. Kegiatan operasional BUMDes Banyuanyar Berkarya berfokus pada 
penyerapan tenaga kerja yang ada di desa, meningkatkan kreatifitas masyarakat sekaligus meningkatkan ekonomi masyarakat atas unit usaha produktif yang ada di Desa Banyuanyar. Hal ini dapat terlihat dari adanya unit-unit usaha yang memanfaatkan potensi desa yang ada di Desa Banyuanyar.

\section{Jenis usaha BUMDes Banyuanyar Berkarya}

BUMDes Banyuanyar Berkarya memiliki beberapa unit usaha yang berjalan dan melakukan aktivitas operasionalnya. Sesuai dengan telaah pustaka awal, yaitu terdapat beberapa jenis usaha dalam pengelolaan BUMDes, maka demikian pula halnya dengan BUMDes Banyuanyar Berkarya juga memiliki beberapa jenis usaha, yaitu sektor perdagangan dan bisnis sosial yang mengacu pada pelayanan umum.

Sektor perdagangan ditunjukkan dengan adanya unit usaha yang memproduksi barang jadi yang berasal dari potensi-potensi desa yang sudah ada di Desa Banyuanyar. Unit usaha BUMDes Banyuanyar Berkarya yang berada pada sektor perdagangan berlandaskan akuisisi. Akuisisi adalah proses perpindahan hak milik dari satu individu ke individu lain, dalam hal ini BUMDes mengakuisisi unit usaha yang berada dalam Kelompok Tani Ternak (KTT) di desa KTT merupakan suatu organisasi yang dimiliki oleh desa sebagai wadah bagi petani dan peternak dalam melakukan usahanya. Bapak B menjelaskan mengenai tahapan proses akuisisi yang dilakukan oleh BUMDes Banyuanyar Berkarya.

“... Kita itu mengakuisisi unit usaha yang sudah ada di Desa Banyuanyar yang dimiliki oleh KTT (Kelompok Tani Ternak). Jadi BUMDes Banyuanyar Berkarya mengakuisisi unit usaha dengan menanamkan modal sebesar lebih dari 50\% untuk unit usaha tersebut sehingga dapat dikelola oleh BUMDes ..."

Sektor perdagangan yang dimiliki oleh BUMDes Banyuanyar Berkarya memiliki unit-unit usaha yang bergerak dibawahnya. Unit-unit usaha unggulan yang ada di BUMDes Banyuanyar Berkarya antara lain: kopi Ngemplak, yogurht dan pengolahan es krim, konsentrat pangan ternak, serta pupuk kompos. Unit usaha produksi kopi yang berada di Dukuh Ngemplak, Desa Banyuanyar ini memanfaatkan potensi desa yang ada dengan menyesuaikan lingkungan Desa Banyuanyar yang baik untuk perkebunan, salah satunya adalah perkebunan kopi yang dikelola masyarakat desa. Produksi kopi ini membantu masyarakat yang memiliki perkebunan kopi untuk mendapatkan pemasukan secara langsung. Hal ini diutarakan langsung kepada Bapak B. 
“...Kami dari BUMDes saat membelikan bahan baku itu pasti memberikan tambahan $30 \%$ dengan harga biasa. Salah satu contohnya kalo ada petani kopi di Ngemplak pasti harga bahan baku itu kita tambahkan harganya 30\% dari harga bahan baku di pasar. Kalo harga di pasar untuk 10.000 rupiah pasti kami dari BUMDes bersedia untuk membelinya sebesar 15.000 rupiah..."

Pada saat ini pembuatan kopi Ngemplak menyediakan 3 jenis kopi yaitu Kopi Jawa, Kopi Robusta, dan Kopi Nangka. Kopi Nangka adalah produk yang menjadi produk utama di Kopi Ngemplak dan telah dijual sampai ke luar pulau Jawa. Bapak $\mathrm{C}$ memberikan pernyataan mengenai penjualan kopi nangka yang sudah sampai di luar Jawa.

“... Kopi Nangka itu udah saya kirim di café-café di Jakarta sama Jayapura mas. Banyak orang juga udah beli Kopi Nangka di kafe ini mas. Pemasaran nya dari orang ke orang dengan bantuan BUMDes dalam melakukan iklannya juga. Jadi kopi Ngemplak ini aja sampai terkenal dimana-mana itu gara-gara BUMDes...”

Unit usaha produksi kopi ini telah memberikan hasil kopi dengan kualitas yang baik. Hasil produksi atas kopi yang kurang maksimal juga dapat memberikan andil dalam pemanfaatan potensi desa dengan menjadikan unit usaha baru yaitu pembuatan konsentrat pangan. Pemanfaatan kopi ini dikonfirmasi oleh Bapak $\mathrm{C}$ yang merupakan pengelola dari produksi kopi di Dukuh Ngemplak.

“...semua dari hulu sampai hilir ada mas, ada kebun kopi, ada limbah kopi nanti dibikin semua. Ada pupuk juga, nanti limbah kopi yang kualitasnya kurang baik untuk dikonsumsi nanti dibuat jadi konsentrat buat pangan ternak ...”

Konsentrat pangan ternak ini menggunakan limbah-limbah tanaman, salah satunya adalah limbah dari produksi kopi untuk diproses menjadi pangan ternak dengan kualitas yang baik. Konsentrat pangan ternak ini membantu para peternak untuk memberikan makan hewan mereka dengan kualitas yang baik tanpa merepotkan para peternak sehingga dapat fokus dalam mengurus ternak

Sapi ternak yang ada di Desa Banyuanyar juga dimanfaatkan untuk unit usaha pengolahan susu seperti yogurth dan es krim. Pengolahan susu ini sudah menghasilkan susu dengan kuantitas yang tidak sedikit dan pengolahan sehingga masyarakat desa menikmati susu tersebut. Pengolahan susu ini sudah masuk dalam berbagai pameran UMKM yang dilakukan oleh pemerintah. 
94 Akuntansi Bisnis dan Manajemen (ABM), Vol. 26, No. 2, Oktober 2019

“...Produk-produk kita itu sekarang udah sampai ke pameranpameran UMKM dimana-mana ada di sekitar daerah mas seperti di Solo dan di Semarang juga..."

Unit usaha pengolahan susu selain telah melakukan ekspansi dalam penyaluran barang produksi sampai keluar area Desa Banyuanyar, unit usaha ini juga melakukan ekspansi usaha untuk membangun jenis usaha yang baru. Jenis usaha ini adalah gabungan dari unit usaha pengolahan susu dan produksi kopi. Jenis usaha ini adalah usaha bersama berupa objek wisata yang akan dijalankan oleh masyarakat Dukuh Ngemplak dengan pengelolaannya dilakukan oleh BUMDes Banyuanyar Berkarya. Jenis usaha ini dinamakan oleh "Kampus Kopi" yaitu singkatan dari "Kampung Susu dan Kopi". Bapak Sutarmo selaku pengawas dari BUMDes Banyuanyar Berkarya menjelaskan realisasi dari pembentukan jenis usaha baru tersebut

“...Kampus Kopi sudah dalam pembentukan mas, ini sudah dibangun sudah dianggarkan juga dalam APBDes, besar juga anggarannya karena tahun ini (2019) Kampus Kopi rencananya juga sudah siap untuk dapat didatangi untuk umum..."

Unit usaha baru ini, dapat menjadi sumber lapangan pekerjaan yang dapat menyerap sumber daya manusia yang tidak sedikit. Bapak Sutarmo menjelaskan mengenai penyerapan sumber daya manusia dari unit usaha "Kampus Kopi"

“...Kampus Kopi bisa buat memberikan pekerjaan juga buat masyarakat di sekitar tempat Kampus Kopi ini mas ...”

BUMDes Banyuanyar Berkarya selain memiliki unit usaha dalam bidang perdagangan juga memiliki unit usaha dalam bidang bisnis sosial yang berlandaskan pelayanan umum. Bisnis sosial yang dilakukan oleh BUMDes ini tidak hanya untuk mencari pendapatan saja melainkan untuk dapat membantu masyarakat dalam melakukan kegiatan sehari-hari. Saat ini bidang ini diisi oleh unit usaha yang bergerak dalam bidang pembayaran yang berbasis online dan pengadaan air bersih. Bapak A memberitahukan mengenai sistem pembayaran online yang tersedia di BUMDes Banyuanyar Berkarya ini.

“... Pembayaran berbasis online itu sudah dibuat dari tahun 2016, unit usaha ini ingin membantu masyarakat untuk melakukan pembayaran di dalam desa saja jadi tidak perlu pergi jauh-jauh keluar desa untuk bayar sesuatu sekaligus BUMDes bisa mendapatkan untung sedikit dari kegiatan ini..." 
Pembayaran berbasis online yang diterapkan oleh BUMDes ini dapat memaksimalkan potensi desa berupa pengembangan tekonologi yang telah dimiliki oleh Desa Banyuanyar. Pembayaran berbasis online saat ini dapat melayani dalam pembayaran Pajak seperti PBB, PPN dan PPh masyarkat. Pak SY mengemukakan alasan pembayaran berbasis online hanya diperuntukan untuk pembayaran pajak.

“... Gini mas, BUMDes dibentuk bukan untuk mematikan usaha milik masyarakat. Masyarakat disini sudah punya usaha agen dari bank-bank yang menyediakan pembayaran PDAM atau pembelian token listrik. Kami melayani pembayaran pajak dikarenakan pembayaran pajak seperti PBB hanya bisa dilakukan di Bank Jateng. Kami ingin mengakomodir masyarakat supaya akses melakukan pembayarannya lebih mudah..."

Bapak E sebagai perwakilan dari masyarakat Desa Banyuanyar mengkonfirmasi informasi tersebut dengan menambahkan cara perkenalan dari pembayaran pajak secara online.

“...Dulu pak lurah melakukan seperti lomba jadi $R T$ yang paling cepat bayar PBB nanti dapat hadiah, jadi masyarakat bayar PBB nya langsung dikumpulin jadi satu RT terus bayarnya di Balai Desa (Kantor BUMDes Banyuanyar Berkarya) sekarang jadi terbiasa bayar disana ...."

Unit usaha lain yang bergerak di bisnis sosial adalah pengadaan air bersih yang mengaliri Desa Banyuanyar. Pak SY menjelaskan mengenai pengadaan air bersih yang disediakan oleh BUMDes.

“... Mata air di Desa Banyuanyar ada dua dan sudah menjadi satu menjadi PAMSIMAS, itu sudah mengalir sampai seluruh titik di Desa Banyuanyar sudah ada meterannya di seluruh rumah. Kalau sumber air minum ini memang tidak mengambil profit sama sekali jadi pengadaan air bersih ini tujuannya murni memudahkan masyarakat dalam mencari air..."

Bapak E juga mengkonfirmasi pernyataan yang diberikan oleh Bapak B mengenai adanya air bersih di Desa Banyuanyar.

“... Di desa juga ada pengadaan air mas, itu meterannya ada di depan rumah saya. Nah itu kan uangnya juga buat desa juga mas.

Jadi kami disini ada sumber airnya gampang mas..." 
96 Akuntansi Bisnis dan Manajemen (ABM), Vol. 26, No. 2, Oktober 2019

\section{Kendala Operasional BUMDes}

BUMDes Banyuanyar Berkarya telah melakukan kegiatan operasionalnya di dalam Desa Banyuanyar selama beberapa tahun ini dan berusaha dalam merealisasikan visi BUMDes. Namun pada kenyataannya terdapat beberapa kendala yang tidak dapat memaksimalkan kinerja operasional dari BUMDes Banyuanyar Berkarya. Permasalahan yang terjadi oleh BUMDes Banyuanyar Berkarya mengacu pada permasalahan teknis dan kesulitan dalam mendapatkan sumber daya yang mumpuni untuk membantu BUMDes Banyuanyar Berkarya

Permasalahan pertama secara teknis yang dihadapi oleh BUMDes Banyuanyar Berkarya adalah sulitnya mencapai target yang dapat dicapai oleh unit usaha yang dimiliki oleh BUMDes Banyuanyar Berkarya. Hal ini terjadi karena beberapa hal, salah satunya adalah kesulitan dalam mendapatkan bahan baku yang baik. Salah satu contoh konkritnya adalah kesulitan Bapak C dalam mendapatkan kopi Nangka yang sulit didapatkan.

“... Saya tidak berani untuk mengambil pesanan yang besar-besar masalahnya kopi Nangka itu sulit dipanennya. Satu bulan ada misalkan itu cuman bisa panen sekitar 2 kilogram saja karena kopi Nangka itu beda sama kopi lain. Lahan buat kopi Nangka itu butuh lebih luas jadinya ga bisa dapat lebih banyak...”

Bapak B juga mengkonfirmasi hal tersebut, sekaligus juga menambahkan beberapa informasi mengenal kendala yang terjadi mengenai kesulitan untuk mencapai target produksi yang diinginkan oleh konsumen luar.

“...Relasi sebenarnya sudah ada mas, dari luar-luar. Tapi untuk produksi jujur saja sulit untuk mencapai targetnya. Bahan baku untuk produksi aja ga cukup untuk memenuhi target yang ingin dicapai. Contoh saja kayak di kopi, Pak Eko hanya ingin kopi yang ada di Banyuanyar ga mau yang lain..."

Permasalahan secara teknis lain yang harus dihadapi oleh BUMDes Banyuanyar Berkarya adalah adanya rasa enggan dari KTT yang ingin diakuisisi dikarenakan rumitnya persyaratan untuk bergabung dalam BUMDes. Salah satu syarat dari proses akuisisi dari unit usaha yang dapat dimiliki oleh BUMDes adalah adanya proses audit atas unit usaha tersebut. Proses audit inilah yang menjadi permasalahan dari BUMDes dalam mengakuisisi unit usaha tersebut. Bapak B memberitahukan alasan sulitnya BUMDes dalam mengakuisisi unit usaha yang dimiliki oleh KTT terkhususnya pada sulitnya melakukan proses audit. 
“... BUMDes sulit untuk mengakuisisi unit usaha yang berada di Desa Banyuanyar ini karena adanya keraguan dari masyarakat yang berada di unit usaha tersebut untuk diperiksa seluruh asetnya. Untuk menjadi unit usaha di BUMDes kan ada syaratnya mas salah satunya harus diaudit unit usahanya. Masyarakatnya tidak mau diperiksa gituan mas, nanti takut asetnya dilihat-lihat sama orang lain (auditor indenpenden)..."

Permasalahan lain yang dihadapi oleh BUMDes Banyuanyar Berkarya adalah adanya rasa tidak ingin dibantu yang dimiliki oleh masyarakat desa yang memiliki unit usaha yang sebenarnya menjanjikan. Masyarakat yang memiliki usaha ini berpikir untuk menolak memberikan barang dagang mereka kepada BUMDes untuk dipromosikan. Bapak B memberikan pernyataan terkait hal berikut.

“... saya itu pernah memberikan bantuan sama masyarkat desa untuk barangnya BUMDes promosiin ke luar desa siapa tahu laku. Masyarakat ga mau dengan alasan kan ini usaha mereka, BUMDes ga usah berurusan dengan usaha mereka kalo laku bagus kalo ga ya sudah..."

BUMDes Banyuanyar Berkarya juga memiliki permasalahan dalam hal sumber daya. Permasalahan sumber daya terkhususnya sumber daya manusia untuk BUMDes Banyuanyar Berkarya adalah masalah yang cukup vital karena menyangkut pada keberlangsungan kegiatan BUMDes dan pengelolaannya. Salah satu permasalahan yang timbul dalam BUMDes Banyuanyar Berkarya adalah sulitnya mendapatkan sumber daya manusia yang dapat mengembangkan potensi Desa Banyuanyar. Kesulitan BUMDes Banyuanyar Berkarya dan Bapak A menjelaskan kesulitan apa saja dalam mencari sumber daya manusia yang berjiwa pengusaha.

“... Kita disini sulitnya adalah mencari sumber daya manusia yang punya jiwa entrepreneur. Kita sudah punya potensi desa yang banyak tapi kita berkekurangan dalam sumber daya manusia itu sendiri yang memiliki pemikiran yang inovatif dan kreatif...”

Permasalahan selanjutnya yang harus dihadapi oleh BUMDes Banyuanyar Berkarya berada di daerah internal BUMDes yaitu kepengurusan BUMDes. Kepengurusan BUMDes sangat penting bagi berjalannya BUMDes dikarenakan pengurus BUMDes dapat memastikan BUMDes melakukan perannya bagi desa dalam pengembangan perekonomian masyarakat. Permasalahan dari BUMDes Banyuanyar Berkarya adalah adanya beberapa 
98 Akuntansi Bisnis dan Manajemen (ABM), Vol. 26, No. 2, Oktober 2019

kali pergantian kepengurusan BUMDes secara penuh dalam 2 tahun berjalannya BUMDes. Adanya pergantian kepengurusan dari BUMDes yang berulang kali terjadi dengan waktu yang relatif singkat ini menyulitkan para pengurus BUMDes yang baru ini untuk mengelola berbagai macam unit usaha yang berada di bawah nauangan BUMDes itu sendiri dikarenakan adanya pengetahun yang kurang mumpuni mengenai permasalahan dasar dari unit-unit usaha yang dimiliki. Bapak B menjelaskan mengapa kepengurusan BUMDes Banyuanyar Berkarya dapat terjadi dengan cepat.

“... Masyarakat itu masih melihat semua hal itu dengan patokan uang mas. Masyarakat masih mikir gimana dapat uang banyak la pendapatan buat para pengurus BUMDes aja masih kecil, mereka ga tahu ada prospek yang sangat menjanjikan dalam BUMDes dikedepannya. Yang penting bagi mereka sekarang dapet duit yang banyak gitu aja mas. Jadi sekarang pengurus setelah saya aja sudah ada pergantian $3 x$ termasuk tahun ini (2019)..."

\section{Pembahasan}

Fokus-fokus yang dimiliki oleh BUMDes Banyuanyar Berkarya yang berkaitan dengan mensejahterakan masyarakat desa dinilai sudah cukup baik, walaupun harus diakui bahwa fokus-fokus yang dilakukan oleh BUMDes Banyuanyar Berkarya belum dapat dilakukan secara menyeluruh. Di satu sisi, misi BUMDes untuk meningkatkan perekonomian masyarakat Desa Banyuanyar sudah dapat dicapai dengan baik. Hal ini ditandai dengan peran BUMDes yang memiliki unit-unit usaha dengan memanfaatkan potensi desa yang ada. Hal ini dinyatakan dengan pembelian bahan baku yang dimiliki oleh masyarakat Desa Banyuanyar kepada unit usaha yang berada dalam BUMDes Banyuanyar Berkarya dengan harga yang cenderung lebih tinggi dari harga yang berada di pasaran. Hal ini tidak hanya membantu BUMDes dalam memanfaatkan aset yang dimiliki desa, namun juga masyarakat juga mendapatkan manfaat dengan pendapatan yang lebih tinggi sekaligus meningkatkan efisiensi masyarakat dalam memperdagangkan barang dagang mereka. Bapak B memberikan contoh sebagai berikut.

“..Salah satu contohnya kalo ada petani kopi di Ngemplak pasti harga bahan baku itu kita tambahkan harganya 30\% dari harga bahan baku di pasar. Kalo harga di pasar untuk 10.000 rupiah pasti kami dari BUMDes bersedia untuk membelinya sebesar 15.000 rupiah..."

Jenis usaha bisnis sosial yang dijalankan oleh BUMDes Banyuanyar Berkarya juga memberikan dampak untuk meningkatkan perekonomian 
masyarkat walaupun efek yang diberikan secara tidak langsung. Bisnis sosial yang dimiliki oleh BUMDes memiliki tujuan untuk mengakomodir masyarakat desa untuk melakukan kegiatan dengan lebih cepat dan efisien. Salah satu contoh konkrit dari jenis usaha bisnis sosial ini adalah adanya unit usaha pembayaran pajak secara online. Hal ini dilakukan dengan memanfaatkan akses internet yang telah disediakan oleh pemerintah desa, dan komputer yang dimiliki pada kantor BUMDes untuk melakukan pembayaran online tersebut. Pembayaran online ini sangat membantu masyarakat desa dalam melakukan pembayaran pajak dengan lebih mudah dan lebih cepat, sehingga masyarakat dapat memanfaatkan waktu dengan lebih baik untuk melakukan kegiatan perekonomian mereka.

Fokus BUMDes Banyuanyar Berkarya selanjutnya adalah meningkatkan kreatifitas masyarakat dalam memanfaatkan potensi desa yang ada. Misi inipun juga telah direalisasikan dengan baik oleh BUMDes Banyuanyar Berkarya dengan adanya unit-unit usaha perdagangan yang beragam. Unit usaha yang dijalankan oleh BUMDes sangat memanfaatkan semua aspek dari potensi desa yang ada sehingga dapat menjadi sesuatu yang lebih bernilai dan dapat dimanfaatkan oleh masyarakat desa untuk kegiatan mereka sehari-hari. Contoh konkritnya adalah unit-unit usaha pada BUMDes Banyuanyar Berkarya yang saling berkesinambungan. Limbah-limbah kopi yang berada pada unit usaha kopi nangka dapat dimanfaatkan oleh unit usaha konsentrat pakan ternak untuk menjadi pakan ternak bagi hewan ternak masyarakat desa, selain susu dan olahan susu yang juga merupakan unit usaha BUMDes hewan ternak juga dimanfaatkan kotorannya untuk menjadi pupuk yang membantu dalam menyuburkan tanah dan siap dibibitkan oleh tanaman masyarakat desa. Hal ini membuat masyarakat desa memiliki kemampuan yang lebih baik dalam memanfaatkan berbagai aset yang dimiliki oleh desa. Peningkatan kreatifitas masyarakat tidak hanya terlihat dari keberagaman unit usaha yang dimiliki, namun juga adanya jenis usaha baru yang dilakukan oleh BUMDes Banyuanyar Berkarya untuk dapat mempromosikan Desa Banyuanyar. Jenis usaha baru yaitu desa wisata yang dinamakan "Kampus Susu" ini sudah dalam pembangunan dan sudah siap untuk dikunjungi dalam beberapa bulan kedepan. Jenis usaha ini tidak hanya menjadi salah satu contoh dari kreatifitas masyarakat namun sekaligus dapat membantu memberikan pendapatan sekaligus tempat mempromosikan barang dagang yang dimiliki oleh BUMDes.

Fokus dari BUMDes Banyuanyar Berkarya yang terakhir adalah penyerapan tenaga kerja dari masyarakat Desa Banyuanyar itu sendiri. Fokus ini adalah fokus yang sulit dicapai dikarenakan adanya permasalahan- 
permasalahan yang dihadapi oleh BUMDes dalam melakukan fokus tersebut. Sebenarnya BUMDes telah melakukan perannya dalam menyerap tenaga kerja yang ada di Desa Banyuanyar. Unit-unit usaha yang dimiliki oleh BUMDes Banyuanyar Berkarya ini memungkinkan banyak tenaga kerja untuk masuk dalam unit usaha tersebut dan membantu unit usaha ini dalam menjalankan kegiatan operasionalnya. Contoh nyatanya adalah dengan adanya Desa Wisata "Kampus Kopi" yang siap dijalankan dan siap menyerap semua tenaga kerja yang ada di area tersebut, begitulah yang dikatakan oleh Bapak D dalam wawancara yang dilakukan.

\section{“...Kampus Kopi bisa buat memberikan pekerjaan juga buat masyarakat di sekitar tempat Kampus Kopi ini mas ..."}

Meski begitu ada beberapa individu yang masih ragu dengan adanya BUMDes Banyuanyar Berkarya. Masyarakat desa masih memikirkan mengenai peran BUMDes dalam meningkatkan perekonomian masyarakat. Hal yang paling pokok adalah masih ragunya KTT-KTT ingin dirangkul oleh BUMDes tetapi terbentur dengan adanya persyaratan mengenai perlunya proses audit. Proses audit sangat dibutuhkan agar unit usaha yang dimiliki oleh BUMDes ini lebih transparan dan menjadi unit usaha yang lebih berkembang lagi dikedepannya karena sudah saling paham dengan informasi unit usaha ini. KTT yang berada di Desa Banyuanyar menganggap proses audit itu hal yang tidak perlu dilakukan karena pihak KTT ada rasa waspada saat asetnya diperiksa oleh auditor independen.Selain permasalahan ini, beberapa individu dalam desa juga tidak ingin BUMDes ikut campur dalam urusan bisnis mereka. Mereka menganggap bahwa usaha yang mereka miliki tidak perlu dibantu dalam hal melakukan pemasaran produk mereka ke luar area desa. Masyarakat desa lebih memilih untuk bersikap acuh tak acuh dengan usaha yang mereka miliki sekaligus meragukan kinerja BUMDes dalam meningkatkan usaha mereka menjadi lebih maju dan lebih baik.

Pihak internal BUMDes juga memiliki permasalahannya sendiri. Banyaknya pergantian kepengurusan BUMDes menyulitkan BUMDes untuk mengembangkan usaha-usaha yang ada. Pergantian kepengurusan ini sudah beberapa kali dilakukan dan sampai saat ini sudah ada kepengurusan yang baru untuk BUMDes Banyuanyar Berkarya. Masyarakat desa masih memiliki anggapan bahwa BUMDes belum dapat menjamin kehidupan mereka menjadi lebih baik. Sulitnya mencari kepengurusan yang tetap untuk internal BUMDes menjadi salah satu bukti sulitnya BUMDes dalam menyerap tenaga kerja yang dimiliki oleh Desa Banyuanyar. Hal ini berimbas pada adanya keterbatasan untuk BUMDes dalam mengelola beberapa unit-unit usaha dengan maksimal 
dikarenakan minimnya pemahaman para pengurus yang bekerja di BUMDes dengan unit-unit usaha yang mereka jalankan dalam BUMDes Banyuanyar Berkarya.

\section{KESIMPULAN, SARAN DAN KETERBATASAN}

BUMDes Banyuanyar Berkarya memiliki peran dalam mengelola dana desa untuk memberikan kesejahteraan masyarakat. Hal ini dibuktikan dengan adanya peran BUMDes dalam meningkatkan kreatifitas masyarakat, meningkatkan perekonomian masyarakat dan memberikan lapangan pekerjaan untuk masyarakat desa yang membutuhkan pekerjaan. Namun terdapat beberapa kendala yang harus dihadapi oleh BUMDes dalam melakukan kegiatan operasionalnya. Kendala-kendala yang dimiliki oleh BUMDes didominasi dengan sulitnya mencari tenaga kerja yang dapat membangun BUMDes dengan baik. Beberapa individu yang berada di Desa Banyuanyar juga masih belum bisa menerima BUMDes dengan baik sehingga mereka memilih untuk mengurus usaha mereka sendiri.

Komunikasi adalah salah satu saran yang dapat diberikan dan dilakukan oleh BUMDes dalam menyelesaikan beberapa kendala BUMDes. Komunikasi yang baik antara pengurus BUMDes dan masyarakat desa dapat membantu BUMDes dalam pemberian informasi yang jelas dan baik sehingga mengurangi konflik dalam penyelesaian masalah. Komunikasi yang dilakukan oleh BUMDes untuk menyelesaikan kendala-kendala yang ada dapat berupa memberikan penyuluhan atau perbincangan dua pihak kepada pihak-pihak yang membutuhkan informasi tersebut.(kendala kesulitan mencari pengurus BUMDes tetap dan kesulitan mengakuisisi unit usaha yang dimiliki KTT) Pemberian informasi yang baik kepada pihak-pihak yang membutuhkan informasi tersebut dapat membantu masyarakat untuk melaksanakan kegiatan perekonomian dengan lebih baik.

Keterbatasan yang dimiliki dalam penelitian ini adalah kurangnya narasumber yang dapat diwawancarai untuk menggali informasi yang lebih rinci mengenal kehadiran BUMDes serta peran BUMDes dalam meningkatkan kesejahteraan masyarakat. Perpindahan kepengurusan yang berganti-ganti membuat informasi sulit untuk didapatkan dikarenakan minimnya informasi yang dimiliki sehingga informasi ini hanya dapat dimiliki oleh pihak-pihak yang memang berada di BUMDes dalam waktu yang cukup lama ataupun para pendiri BUMDes yang mengenal dengan 
102 Akuntansi Bisnis dan Manajemen (ABM), Vol. 26, No. 2, Oktober 2019

baik pengelolaan BUMDes dan masa depan yang diinginkan untuk berjalannya BUMDes.

\section{DAFTAR PUSTAKA}

Agunggunanto, E. Y., Arianti, F., Kushartono, E. W., \& Darwanto. (2016). Pengembangan Desa Mandiri Melalui Pengelolaan Badan Usaha Milik Desa (BUMDes). Jurnal Dinamika Ekonomi Dan Bisnis, 13(No 1), 67-81.

Anggraeni, M. R. R. S. (2016). Peranan Badan Usaha Milik Desa (BUMDes) Pada Kesejahteraan Masyarakat Pedesaan Studi Pada BUMDes Di Gunung Kidul, Yogyakarta. MODUS, 28(2), 155-167.

Astuti, P. F., \& Warsito. (2017). Pelaksanaan Fungsi Pengawasan BUMDes Desa Ponggok Kecamatan Polanharjo Kabupaten Klaten. Journal of Politic and Government Studies, 6(2), 291-300.

Budiono, P. (2015). Implementasi Kebijakan Badan Usaha Milik Desa (Bumdes) Di Bojonegoro (Studi di Desa Ngringinrejo Kecamatan Kalitidu Dan Desa Kedungprimpen Kecamatan Kanor). Jurnal Politik Muda, 4(1), 116-125.

Direktorat Jenderal Perimbangan Keuangan. (2017). Buku Pintar Dana Desa : "Dana Desa Untuk Kesejahteraan Masyarakat: Menciptakan Lapangan Kerja, Mengatasi Kesenjangan, dan Mengentaskan Kemiskinan. Kementrian Keuangan. Direktorat Jenderal Perimbangan Keuangan.

Menteri Dalam Negeri Republik Indonesia. (2014). Permendagri Nomor 113 Tahun 2014 Tentang Pengelolaan Keuangan Desa. Kementrian Desa, Pembangunan Desa Tertinggal dan Transmigrasi Republik Indonesia.

Menteri Desa Pembangunan Desa Tertinggal dan Transmigrasi Republik Indonesia. (2015). Permendesa No 4 Tahun 2015 Mengenai Pendirian, Pengurusan dan Pengelolaan, dan Pembubaran Badan Usaha Milik Desa. Jakarta, Indonesia: Kementerian Desa, Pembangunan Desa Tertinggal dan Transmigrasi Republik Indonesia.

Pemerintah Desa Banyuanyar. (2017). Banyuanyar Berkarya. Retrieved September 25, 2018, from https://banyuanyar.desa.id/potensidesa-2Banyuanyar.Berkarya.html

Presiden Republik Indonesia. (2014a). Peraturan Pemerintah Nomor 60 Tahun 2014 Mengenai Dana Desa yang Bersumber dari Anggaran Pendapatan dan Belanja Daerah. Jakarta: Kementerian Sekretariat Republik Indonesia.

Presiden Republik Indonesia. (2014b). Undang-Undang Nomor 6 Tahun 2014 Mengenai Desa. Jakarta: Kementrian Sekretariat Negara Republik Indonesia.

Ramadana, C. B., Ribawanto, H., \& Suwondo. (2013). Keberadaan Badan 
Usaha Milik Desa (BUMDes) Sebagai Penguatan Ekonomi Desa (Studi di Desa Landungsari, Kecamatan Dau, Kabupaten Malang). Jurnal Administrasi Publik (JAP), 53(9), 1689-1699. https://doi.org/10.1017/CBO9781107415324.004

Ridlwan, Z. (2014). Urgensi Badan Usaha Milik Desa (Bumdes) Dalam Pembangun Perekonomian Desa. Fiat Justisia Jurnal Ilmu Hukum, 8 no. 3, 424-440. https://doi.org/10.25041/fiatjustisia.v8no3.314

Tribun News. (2018). Kemendes PDTT Gelar Forum Tematik Bakohumas Sosialisasikan Pentingnya BUMDes. Retrieved September 16, 2018, from http://www.tribunnews.com/nasional/2018/07/25/kemendes-pdtt-gelarforum-tematik-bakohumas-sosialisasikan-pentingnya-bumdes 